\title{
A Study on the Reform of College English Pragmatic Teaching Based on Mixed Teaching Methods
}

\author{
Qingyan Meng* \\ Harbin Huade College, Harbin 150025, China \\ *Corresponding author: Qingyan Meng, mengqingyanabby@163.com
}

\begin{abstract}
The college English pragmatic teaching approach, which seeks to foster students' English for all-round growth, is constantly developing with the ongoing development and improvement of education in China. As a result, during the implementation of college English pragmatic teaching, teachers realized their educational responsibility and implemented the mixed teaching style in a reasonable manner ${ }^{[1]}$. English pragmatic teaching content has grown in depth, enhancing students' perceptions of learning and allowing them to participate more fully in knowledge acquisition. Furthermore, it creates a solid basis for college students' follow-up English level exams, allowing them to steadily develop their English thinking abilities. This study focuses on the mixed-methods reform of college English pragmatic teaching. The author puts forward reasonable suggestions combined with his own teaching experience.
\end{abstract}

Keywords: Mixed teaching; College English pragmatic teaching; Reform research

Publication date: December 2021; Online publication: January 24, 2022

\section{Introduction}

College students already have a good command of the English language. The goal of incorporating English pragmatic teaching content into college classrooms is to improve students' English skills and obtain double the outcome with half the work. As a result, while implementing college English pragmatic teaching, we should stress the use of mixed teaching modes, begin by developing students' English core literacy, alter teaching contents and teaching forms, and provide a positive learning environment for students ${ }^{[2]}$. Simultaneously, as teachers, they must recognize the importance of mixed teaching techniques, carefully create each teaching link based on the students' individual learning needs, and promote the quality and reform of college English pragmatic teaching in China.

\subsection{Connotation of mixed teaching mode}

The mixed teaching mode, in contrast to traditional teaching, overcomes the constraints of the previous teaching classroom by combining online and offline approaches to assist students consolidate their knowledge material and increase their learning impact. The most important aspect of mixed teaching is that it encourages students to go deeper into their learning and allows them to comprehend the substance of theoretical knowledge. It is undeniably a difficulty to enhance college English classrooms if this teaching technique is used with pragmatic college English teaching. Students must examine English difficulties under the supervision of mixed teaching, eventually answer problems, increase students' awareness of independent learning, and improve their participation in knowledge learning. 


\section{The importance of college English pragmatic teaching reform with mixed teaching}

\subsection{Meet students' development needs}

College students are about to secure employment. The need for skills in numerous industries has significantly grown in recent years, putting more pressure on college students to find work. The university classroom, as the primary learning environment for students, should take the lead in fostering abilities. As a result, it is critical to reform college pragmatic teaching based on blended teaching. Students will regain control of the English pragmatic classroom, which will improve learning efficiency, satisfy students' developmental requirements, and establish a solid basis for their future growth.

\subsection{Respond to the call of the new curriculum reform}

The new curriculum reform will correct college English pragmatic teaching materials and teaching methods in today's educational environment. To guarantee the smooth growth of college English teaching, colleges and universities must fulfil the demands of correction and connect the educational policies set by their superiors with the actual teaching materials. The reasoning presented here is insufficient.

\section{Analysis of pragmatic teaching in college English}

At present, there are still many problems in college English pragmatic teaching, which affect students' learning efficiency to a certain extent.

\subsection{Lack of perfect teaching links}

Teachers should increase teaching connections at each teaching level, and modern teaching links should encompass course supervision, instruction, and assessment. Teachers, on the other hand, pay more attention to the teaching link in the actual process of college English instruction, continually prolonging the teaching link duration and increasing the explanation of theoretical information. College pragmatic instruction is kept on the surface in this teaching technique ${ }^{[3]}$.

\subsection{Neglect students' learning status}

Some teachers continue to take the lead in the classroom due to their backward teaching style. They organize students' learning assignments and establish learning objectives, making the English classroom more restrictive and having a poor teaching effect.

\subsection{Teachers do not have enough awareness of the new educational concept}

Many teachers have not been kept up to date due to the constant appearance of new educational techniques and concepts. In the classroom, students' English thinking abilities are still being hindered by the employment of outdated teaching methods.

\section{A study on the reform of college English pragmatic teaching based on mixed teaching}

\subsection{Improve teaching links and promote the integration of mixed teaching and practical teaching}

The whole classroom teaching linkages, including course guiding, teaching, and teacher assessment, were discussed in the preceding article. Teachers can begin by connecting the teaching links, no longer viewing each teaching link as a distinct individual, and allowing them to interact and promote one another in order to apply college English pragmatic teaching. The specific methods are discussed below. 
The first is the course guidance link, which is required for follow-up teaching activities to function. Its goal is to assist students immediately enter the learning state and stay focused in the classroom. The situational method is the most typical strategy to direct the class in order to improve the teaching classroom's interest and engage the learning environment.

The teaching link is the second. From a typical teaching perspective, there are misconceptions in the teaching link. The teaching link is a method of cultivating students' overall growth as well as imparting students' information and fundamental abilities. As a result, teachers should actively adapt their teaching identities, complete the teaching-to-learning process, provide students with more independent learning space, and encourage students to enhance their learning efficiency ${ }^{[4]}$. Construction of teaching links allows for autonomous learning and group cooperative learning, as well as the creation of an autonomous learning platform, efficient college English pragmatic teaching classrooms, and mixed teaching. The final section is a link to a teaching assessment. We should respect students' learning status, use a variety of assessment techniques, allow students to truly understand their own problems, optimize their own learning effect under the guidance of teachers, and achieve a scientific and unified teaching effect while evaluating methods ${ }^{[1]}$.

Teachers utilize multimedia to play video material, let students estimate the learning theme, mobilize learning motivation, and provoke students' discussion; for example, in the process of guiding students to explore English knowledge, in the actual teaching, and in the course guidance link. To guarantee the smooth flow of instructional activities, teachers set challenges and arrange students in such a way to complete the learning tasks through group cooperation. "Students, today we will learn English pragmatic knowledge," said a teacher in a teaching assessment. Many students performed very well, but some students did not actively participate in the study. The author hopes that it can be corrected in the future.

\subsection{Make rational use of information technology to promote the integration of mixed teaching and practical teaching}

The information technology era has arrived to make people's access to knowledge and work easier. Saving time and using a large number of resources are two of the most important qualities of information technology. College English pragmatic teaching is based on the mixed teaching method, information technology must be integrated, online and offline teaching must be conducted, and students' perceptions of English pragmatic knowledge must be improved. Teachers should allocate curriculum resources for online teaching that include four parts.

One is learning English pragmatic theory, the other is extracurricular extension of English pragmatics, the third is English pragmatic classroom practice, and the fourth is English pragmatic homework arrangement. Students view the teacher's explanation video online and complete the learning activities in the order prescribed by the online course's teaching sequence. Simultaneously, teachers can inquire students' learning situations online as student guides and guides, in order to analyze students' learning progress and adapt follow-up curricular materials. Auxiliary teaching job includes offline instruction and information technology. Information technology is directly linked to the presentation of classroom teaching materials and the building of situational teaching models in order to improve students' learning efficiency and increase learning management ${ }^{[2]}$.

Using the online teaching model as an example, in the process of enabling students to study college English pragmatic knowledge, teachers should first separate students' intelligence into intellectual and nonintellectual abilities. Second, according to the stratification findings, distinct English pragmatic video teaching materials are recorded to complement different learning resources. Finally, the teacher uploads the course materials so that the students may learn from them. The teacher can correct completed assignments online and help students in correcting problems in their learning ${ }^{[3]}$. 


\subsection{Improve teachers' teaching ability and promote the combination of mixed teaching methods and practical teaching}

Teachers explain, teach, and answer doubts. Schools should pay attention to teachers' teaching levels in the process of college pragmatic teaching based on mixed teaching, especially under the mixed teaching mode, where teachers should have information literacy and professional literacy abilities, arrange students' online and offline teaching activities reasonably, understand the function of information technology, and improve the quality of English teaching. The specific methods are discussed below.

First, engage in teaching and research activities. Teachers use teaching and research activities to examine the content of a subject and present fair opinion. The university's research topic should be the reform of college English pragmatic teaching in mixed classes. According to the university's unique condition, teaching and research faculty should examine it from the perspectives of students and teachers, as well as a wide range of nationally and internationally references, and devise targeted schemes to improve the feasibility of subject debate. Following that, the school will use the discussion approaches in specific teaching to increase the teaching quality even further.

Second, create activities that match teachers with apprentices. Different teaching levels exist among college English professors. Through teacher apprentice pairing, schools should strengthen the general information literacy and professional literacy of school teachers. The master and apprentice encourage and assist one another in this process, which not only improves the master's teaching level but also allows the apprentice to gain teaching experience, allowing them to obtain double the result with half the work.

Finally, implement an evaluation system. Teachers' evaluations used to be more focused on their understanding of theoretical knowledge and less on their practical abilities. As a result, schools should develop an integrated assessment activity of practice and written examination to improve the validity and effectiveness of assessment results ${ }^{[4]}$.

For example, in the process of leading teachers to learn information technology and teaching knowledge, the school takes the apprenticeship activity as an example. To begin, the school groups experienced teachers and new teachers into a single apprenticeship group. The apprenticeship activity uses a rotation approach, with teachers and apprentices swapping places every week to keep the apprenticeship activity new. Second, the school assigns growth assignments to each pair of teachers and apprentices, as well as defining their objectives. To assist the apprentice in realizing the problem, the master must accompany the apprentice and listen to and analyze the class. Finally, the school evaluates each pair of teachers and apprentices on a regular basis. Teachers and apprentices who do well should be praised and encouraged in order to increase their self-esteem.

\section{Conclusion}

In other words, to increase the quality of college pragmatic teaching, teachers should have information literacy and professional literacy abilities in the process of college English pragmatic teaching reform, which is based on mixed teaching. In the classroom, we should first enhance the teaching links, encourage the integration of various teaching techniques, and ensure that each teaching link is balanced. Second, make effective use of information technology, including online and offline instruction, clarification of students' learning objectives, and increased learning efficiency. Finally, teachers, as the major body of education implementation, should create educational concepts and contribute to China's educational reform to raise their teaching level.

\section{Disclosure statement}

The author declares that there is no conflict of interest. 


\section{References}

[1] Department of Higher Education, 2007, Ministry of Education. College English Teaching Requirements. Shanghai Foreign Language Education Press, Shanghai.

[2] Li K, Zhao J, 2004, Principle and Application Model of Blended Learning. Research on Audio Visual Education, 2004(7): 1-6.

[3] Cai J, 2004, College English Curriculum Requirements and Its Consistency and Foresight. Foreign Language World, 2004(5): 10-17.

[4] He K, 2005, New Development of Educational Technology Theory from Blending Learning. Journal of National Institute of Educational Administration, 2005(9): 37-48. 